\title{
Developing a Model of Character Education of $5 t$-Based Pencak Silat
}

\author{
Prabowo Hadi Saputro \\ Master Program in Sport Sciences \\ Universitas Negeri Yogyakarta \\ Yogyakarta, Indonesia \\ prabowohadisaputro@gmail.com
}

\author{
Siswantoyo \\ Faculty of Sport Sciences \\ Universitas Negeri Yogyakarta \\ Yogyakarta, Indonesia \\ siswantoyo@uny.ac.id
}

\begin{abstract}
-this research aims to develop a model of character education of 5T-based pencak Silat that can be used by athletes and coaches of pencak silat. The method used in this research was research and development. This steps were adapted from Sugiono's research step which was adapted into 10 steps. The small group trails were conducted on eight coaches, while the large group trials were conducted on 24 coaches and an effectiveness test was administered to 35 athletes. The research instruments used to collect the data were evaluation sheets or form and assessment scale questionnaire. The data of the evaluation results were in the form of descriptive qualitative and quantitative percentage. The result showed that the developed model of character education of 5Tbased pencak silat is feasible to use to inculcate character education. This is shown in the results of several assessments conducted by the material expert, media expert, and language expert. The final result of the product assessment by the material expert indicated that the learning module was "feasible" with a percentage of $86 \%$ and the final result of the product assessment by the media expert indicated a "feasible" result with a percentage of $77 \%$ and the language expert indicated a "feasible" result with a percentage of $90 \%$. The small group trial results show that the model is "feasible" with a percentage of $94 \%$, while the results of large group trials show it is "feasible" with a percentage of $85 \%$. The effectiveness test results used a T-test of $19.556>2.032$ table $t$, and a significance value of $0.000<0.05$. Therefore, the module is effective to be used for athletes and coaches of pencak silat.
\end{abstract}

Keywords—character education, pencak silat,

\section{INTRODUCTION}

Globalization is a reality that cannot be avoided in this era. Indonesia, as one of the developing countries, also experiences the impact and change due to the globalization. There are some negative impacts that the Indonesian community must be aware of. Violence between children and adolescents, crimes against friends, cheating habits of teenagers, theft, drug abuse, pornography, and the destruction of property of others has become a social problem that until now have not been able to be completely resolved, hence the importance of character education [1]. The purpose of education is to build character behavior in order to have the knowledge, skills, attitude and nobility and have a competitive edge in the face of globalization [2]. National education has a function to develop ability and form the character of an individual. The purpose of education is to form character contained in unity and is important in personal behavior and attitude to life [3]. Whereas according to [4] the main goal of character, education is the character development of students.
Character education programs focus on social, emotional and personal development [5].

A person's "character" refers to the disposition and habits that determine the way that a person normally responds to desires, fears, challenges, opportunities, failures and successes [6]. The decline in morality as a result of globalization causes the character of the nation's children to become fragile and easily tossed around. This leads to moral decadence and the spirit of creativity and productivity of the nation declines, which is replaced by the spirit of hedonism and consumerism. This is where the importance of internalizing character education more intensively, both in intra-curricular and extracurricular programs, as a foundation that can equip students to meet their future. A strong character will produce a strong mentality, a strong spirit, will to never give up, be persistent, work hard, not spoiled, and dare to proceed. Character education is defined as education practices that encourage character development [7]. Character education lessons should be fun, catchy and presented in such a way [8]. Through education of character, students are able to protect themselves, to form selfsupporting personality which is based on their faith, have a good attitude in respecting each other and people who have a different religion, and so on. [9]. Though it takes a very long time, the world education system has started in many forms and some systems have begun educating students of various ages, and beliefs about the value of the character. Children in the future, have to do with the level of characters embedded in him, or her, through character education [10]. One of the education which can develop strong character for children is by providing pencak silat education. Pencak silat education can develop five distinctive character values, namely the character of Takwa, Tangguh, Trengginas, Tanggap, and Tanggon (5T) [11]. In the 38 observations of research on pencak silat in Universitas Negeri Yogyakarta, no one has revealed specifically about the development of the pencak silat character education model.

\section{Character EdUCATION}

The purpose of education is to form characters that are manifested in the essential unity of the subject with the behaviors and attitudes of life he/she has [12]. A strong character is the most important quality in family, school and society so as to be worthy and virtuous [13]. According to education, school is an activity environment in terms of practice and used for learning and development [14]. 
Character education is moral education that determines how a character's role would be to create a good life [15].

Character is something that qualifies a person. Character becomes an identity that overcomes the ever-changing contingent experience. From the maturity of this character, the quality of a person is measured. Character building has been a basic idea about education itself. In Greek and Roman literature, ideas about human education in modern society culminated in Hegelian spirit awareness that culminates in the awareness of dialectics as an integral part of the approach to character formation through education. Character education is an effort to help the development of the souls of children both physically and mentally, from their nature to a humane and better civilization [16]. Character education will be more meaningful if carried out from early childhood [17]. Character education is described as a special curriculum developed to teach or foster children about the qualities and traits of good character [18].

Character is the values of human behavior that relate to God Almighty, self, fellow human beings, environment, and nationality which are manifested in thoughts, attitudes, feelings, words, and actions based on the norms of religion, law, manners, culture, and customs. Beliefs make a guideline in an individual's behavior because values are believed to provide benefits in life. When character education is on troubled children, which caused a direct impact on the emotions, attitudes and behaviour of children, the role of the teacher becomes more important [19].

\section{A. Character Education Model}

There are 6 character pillars as follows: 1 . Trustworthiness 2. Honesty 3. Caring 4. Respect and attention 5. Citizenship 6. Responsibility [20] while based on character development curriculum:1) Caring, compassion, kindness, and empathy, 2) Citizenship, 3) courage, 4) Fairness, 5) Honesty and trustworthiness, 6) Integrity, 7) Leadership, 8) Perseverance in establishing and attaining goals, 9) Respect, 10) responsibility, and 11) Team work and cooperation [21]. The character education partnership organization has identified a set of principles for an effective character education program. These include: 1) foundation of good character, 2) comprehensive character definitions, 3) character development approaches, 4) caring school community, 5) moral action opportunities, 6) meaningful academic curriculum, 7) students' self-motivation, 8) ethical learning community school staff, 9) shared leadership, 10) engaged families and communities, and 11) assessment based school culture [22].

\section{B. Pencak Silat}

Pencak silat is a self-defense method created to defend from hazards that can threaten safety and survival [23]. Pencak silat is an Indonesian martial sport that has the noble values contained in it. [24]It states :"Pencak silat is a regular attack-defend-movement according to the system of time, place, climate, by always maintaining each other's honor and, not wanting to hurt feelings, very closely related to human spirit and immediately surrender to God Almighty. Therefore, pencak silat is very closely related to the outer and spiritual aspects ". In the pencak part of a performance, they learn the techniques of open hand combat between a pair, or pairs, of protagonists in the second and final part, called silat [25].

Takwa means to believe in The One God. Tanggap means sensitive, caring, anticipatory, proactive, and has continuity that is carried out and developments that occur in all aspects, balance, and challenges that accompany it through brave, introspective, and continuously improving the quality of oneself. Tangguh means tenacity, never gives up, and able to develop its capabilities in answering challenges that are tackling in order to uphold truth, honesty and justice. Tanggon means able to withstand all temptations and trials that have a sense of self-worth and a thick personality, full of calculations in acting, discipline, and being responsible and complying with legal, social and religious norms. Trengginas in the Japanese language means energetic, active, creative, and innovative, thinking broadly and able to work hard to pursue quality and beneficial progress for themselves and society based on an attitude of willingness to build themselves and the attitude of being responsible for the development of society [11].

\section{MATERIAL \& METHODOLOGY}

\section{A. Participants}

This research was conducted in pencak silat schools in Yogyakarta. This study began in January 2018 until June 2018. The subjects of this study were pencak silat athletes in Yogyakarta. Small group trials were conducted on 8 pencak silat trainers, while a large group trials were conducted on 24 pencak silat trainers and an effectiveness test with 35 pencak silat athletes.

\section{B. Data Collection Procedure}

Research conducted by researchers is research and development [26], the steps of research and development are as follows: (1) potential and problems, (2) flow data, (3) product design, (4) product validation, (5) product revision, (6) product trials, (7) product revisions, (8) usage trials, (9) product revisions, (10) final products. To find out the results of both before and after, product trials needed to learn information about effectiveness and cannot be used for pencak silat.

\section{Data Analysis Technique}

The data used in this research are quantitative and qualitative. The questionnaire used in the study is an assessment questionnaire. The feasibility of the 5T-based pencak silat character education book in this development research is classified into four categories of as follows:

TABLE I. FeAsibILITy PERCENTAGE

\begin{tabular}{ccc}
\hline No. & Score (\%) & $\begin{array}{c}\text { Categories Of } \\
\text { Feasibility }\end{array}$ \\
\hline 1. & $76 \%-100 \%$ & Feasible \\
\hline 2. & $56 \%-75 \%$ & Quite feasible \\
\hline 3. & $40-55 \%$ & Less feasible \\
\hline 4. & $<40 \%$ & Not feasible
\end{tabular}


The effectiveness test of the model is intended to obtain information about whether or not product development is effective when applied in the training process at the martial arts college. The effectiveness test of the product was carried out for 1 month, from 4 May 2018 to 5 June 2018. In analyzing the results, the effectiveness test using t test was carried out with the help of SPSS 23 program to determine the improvement of the results of pencak silat character education before and after treatment.

\section{RESULTS AND DISCUSSION}

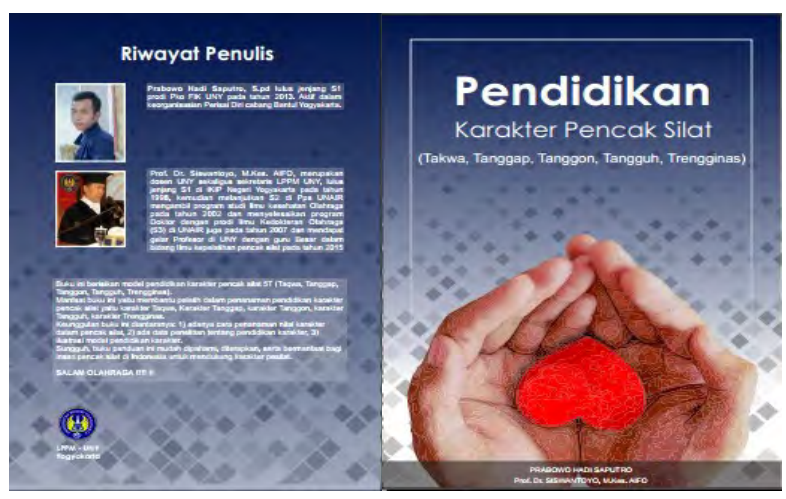

Fig. 1. Initial Product

TABLE II. SCORE ASSESSMENT FROM MATERIAL EXPERTS

\begin{tabular}{|c|c|c|c|c|c|c|}
\hline \multirow{2}{*}{ NO } & \multirow{2}{*}{ Assessed Aspect } & \multicolumn{4}{|c|}{ Assessment } & \multirow{2}{*}{ Note } \\
\hline & & 1 & 2 & 3 & 4 & \\
\hline 1. & $\begin{array}{l}\text { The material for the } \\
5 \text { T-based pencak silat } \\
\text { character education } \\
\text { model is in accordance } \\
\text { with the basic theory } \\
\text { of pencak silat } \\
\text { character education. }\end{array}$ & & & & $\sqrt{ }$ & \\
\hline 2. & $\begin{array}{l}\text { The material presented } \\
\text { in the } 5 \mathrm{~T} \text {-based } \\
\text { pencak silat character } \\
\text { education model is } \\
\text { easily understood by } \\
\text { athletes. }\end{array}$ & & & $\sqrt{ }$ & & \\
\hline 3. & $\begin{array}{l}\text { The material presented } \\
\text { is simple and clear. }\end{array}$ & & & & $\sqrt{ }$ & \\
\hline 4. & $\begin{array}{l}\text { The title of the book is } \\
\text { in accordance with the } \\
\text { material. }\end{array}$ & & & $\sqrt{ }$ & & \\
\hline 5. & $\begin{array}{l}\text { The material is useful } \\
\text { for both trainers and } \\
\text { pencak silat athletes. }\end{array}$ & & & & $\sqrt{ }$ & \\
\hline 6. & $\begin{array}{l}\text { Material is delivered } \\
\text { in coherent. }\end{array}$ & & & & $\sqrt{ }$ & \\
\hline 7. & $\begin{array}{l}\text { The material presented } \\
\text { has a clear purpose for } \\
\text { the cultivation of } \\
\text { athletes' character } \\
\text { education. }\end{array}$ & & & $\sqrt{ }$ & & \\
\hline 8. & $\begin{array}{l}\text { The language used is } \\
\text { easily understood by } \\
\text { athletes. }\end{array}$ & & & $\sqrt{ }$ & & \\
\hline 9. & $\begin{array}{l}\text { Character education } \\
\text { model writing is in } \\
\text { accordance with the } \\
\text { cultivation of } 5 \mathrm{~T}\end{array}$ & & & $\sqrt{ }$ & & \\
\hline & Sum & & & 15 & 16 & \multirow[t]{3}{*}{ Feasible } \\
\hline & Total Scale & \multicolumn{4}{|c|}{31} & \\
\hline & Criteria Aspect & \multicolumn{4}{|c|}{36} & \\
\hline
\end{tabular}

TABLE III. SCORE ASSESSMENT From MATERIAL EXPERT

\begin{tabular}{|c|c|c|c|c|c|c|}
\hline \multirow{2}{*}{ NO. } & \multirow{2}{*}{ Assessed Aspect } & \multicolumn{4}{|c|}{ Assessment } & \multirow[t]{2}{*}{ Note } \\
\hline & & 1 & 2 & 3 & 4 & \\
\hline 1. & $\begin{array}{l}\text { The size of the book } \\
\text { is appropriate }\end{array}$ & & & $\sqrt{ }$ & & \\
\hline 2. & $\begin{array}{l}\text { The explanation in the } \\
\text { book is appropriate }\end{array}$ & & & $\sqrt{ }$ & & \\
\hline 3. & $\begin{array}{l}\text { Photo arrangement } \\
\text { activities are } \\
\text { appropriate }\end{array}$ & & & $\sqrt{ }$ & & \\
\hline 4. & $\begin{array}{l}\text { The arrangement of } \\
\text { pictures and writing } \\
\text { on the book cover is } \\
\text { interesting }\end{array}$ & & & $\sqrt{ }$ & & \\
\hline 5. & $\begin{array}{l}\text { The appearance of the } \\
\text { front and back images } \\
\text { is interesting }\end{array}$ & & & & $\sqrt{ }$ & \\
\hline 6. & $\begin{array}{l}\text { The selection of paper } \\
\text { for the books is good }\end{array}$ & & & $\sqrt{ }$ & & \\
\hline 7. & $\begin{array}{l}\text { The size of activity } \\
\text { photos is appropriate }\end{array}$ & & & $\sqrt{ }$ & & \\
\hline 8. & $\begin{array}{l}\text { The display of book } \\
\text { letters is appropriate. }\end{array}$ & & & $\sqrt{ }$ & & \\
\hline 9. & $\begin{array}{l}\text { The type of letter used } \\
\text { is appropriate. }\end{array}$ & & & $\sqrt{ }$ & & \\
\hline 10. & $\begin{array}{l}\text { The exact layout of } \\
\text { the text is good }\end{array}$ & & & $\sqrt{ }$ & & \\
\hline 11. & $\begin{array}{l}\text { The type and size of } \\
\text { the letters are easy to } \\
\text { read }\end{array}$ & & & $\sqrt{ }$ & & \\
\hline & Sum & & & 30 & 4 & Feasible \\
\hline & Total Scale & \multicolumn{4}{|c|}{34} & \\
\hline & Criteria Aspect & \multicolumn{4}{|c|}{44} & \\
\hline
\end{tabular}

\section{TABLE IV. SCORE ASSESSMENT} FROM LINGUIST

\begin{tabular}{|c|c|c|c|c|c|c|}
\hline \multirow{2}{*}{ NO. } & \multirow{2}{*}{ Assessed Aspect } & \multicolumn{4}{|c|}{ Assessment } & \multirow[t]{2}{*}{ Note } \\
\hline & & 1 & 2 & 3 & 4 & \\
\hline 1. & $\begin{array}{l}\text { The language used is in } \\
\text { accordance with language } \\
\text { norms. }\end{array}$ & & & $\sqrt{ }$ & & \\
\hline 2. & $\begin{array}{l}\text { The language used is } \\
\text { straightforward and easy to } \\
\text { understand }\end{array}$ & & & & $\sqrt{ }$ & \\
\hline 3. & $\begin{array}{l}\text { The language used is } \\
\text { communicative }\end{array}$ & & & & $\sqrt{ }$ & \\
\hline 4. & $\begin{array}{l}\text { The choice of language in } \\
\text { describing the material is } \\
\text { correct. }\end{array}$ & & & & $\sqrt{ }$ & \\
\hline 5. & $\begin{array}{l}\text { The sentence used is } \\
\text { simple and goes straight to } \\
\text { the target reader }\end{array}$ & & & & $\sqrt{ }$ & \\
\hline 6. & The spelling used is correct & & & $\sqrt{ }$ & & \\
\hline 7. & $\begin{array}{l}\text { The use of the term is } \\
\text { consistent }\end{array}$ & & & & $\sqrt{ }$ & \\
\hline 8. & $\begin{array}{l}\text { The use of symbols or } \\
\text { icons is consistent }\end{array}$ & & & $\sqrt{ }$ & & \\
\hline & Sum & & & 9 & 20 & $\begin{array}{l}\text { Feasibl } \\
\mathrm{e}\end{array}$ \\
\hline & Total Scale & & & 29 & & \\
\hline & Criteria Aspect & & & 32 & & \\
\hline
\end{tabular}

The subjects of this small-scale trial were pencak silat trainers consisting of 8 people from 3 pencak silat schools (Perisai Diri, Tapak Suci, and Perpi Harimurti). The results are as follows: 
TABLE V. SMALL GROUP TRIAL RESULTS

\begin{tabular}{|c|c|c|c|c|c|}
\hline No & $\begin{array}{c}\text { Assessed } \\
\text { Aspect }\end{array}$ & Min & Max & $\%$ & Category \\
\hline 1. & Display & 303 & 320 & $94 \%$ & Feasible \\
\hline 2. & Material & 266 & 280 & $95 \%$ & Feasible \\
\hline \multicolumn{2}{|c|}{ Total Score } & 569 & 600 & $94 \%$ & Feasible \\
\hline
\end{tabular}

Large-scale trials were carried out on 24 trainers from pencak silat schools in Yogyakarta

\section{TABLE VI. LARGE GROUP TRIAL RESULTS}

\begin{tabular}{|c|c|c|c|c|c|}
\hline No. & $\begin{array}{c}\text { Assessed } \\
\text { Aspect }\end{array}$ & Min & Max & $\mathbf{( \% )}$ & Category \\
\hline 1. & Display & 802 & 960 & $83 \%$ & Feasible \\
\hline 2. & Material & 737 & 840 & $87 \%$ & Feasible \\
\hline \multicolumn{2}{|c|}{ Total Score } & 1539 & 1800 & $85 \%$ & Feasible \\
\hline
\end{tabular}

The effectiveness test was carried out on 35 athletes trained by Perisai Diri and the Persaudaraan Setia Hati Terate. Pencak silat character education book contains 5Tbased pencak silat character education models (Takwa, Tanggap, Tanggon, Tangguh and Trengginas). The character education model applied is as follows:

1. Takwa

Pray before and after carrying out pencak silat activities, uphold the truth, uphold honesty, uphold justice, and be able to create peace with other members.

\section{Tanggap}

Build good relationships with others, paying attention to environmental hygiene, helping activities in pencak silat school happily, responding quickly, being able to manage emotions, being able to motivate themselves and smartly outperform opponents' abilities quickly and accurately.

3. Tanggon

Overcoming every difficulty with rigidity, hold the test against temptation, has a disciplined attitude, comply with agreed rules, responsible for everything he/she does, and not easily provoked by other members.

4. Tangguh

Having an unyielding soul, considering the good and bad of a problem faced, not in a hurry in making decisions, facing the challenges in every difficulty, being able to develop their abilities, and being tough in dealing with problems.

\section{Trengginas}

Wise in making decisions, having high confidence, being creative in developing a pencak silat movement, able to work hard in practice, actively following every training given by the coach, initiatively find opportunities to outperform opponents, and bring new and more innovative ideas.

Based on the results of the pretest and posttest, it can be seen that the $t$ count is 19.556 and table $2.032(\mathrm{df}=(\mathrm{n}-1)=$ $34)$ with a significant value of $p$ of 0.000 . Therefore $t$ count $19.556>t$ table 2.032 , and significant value $0.000<0.05$. So it can be concluded that the pencak silat character education model is effectively used as the cultivation of pencak silat character education.

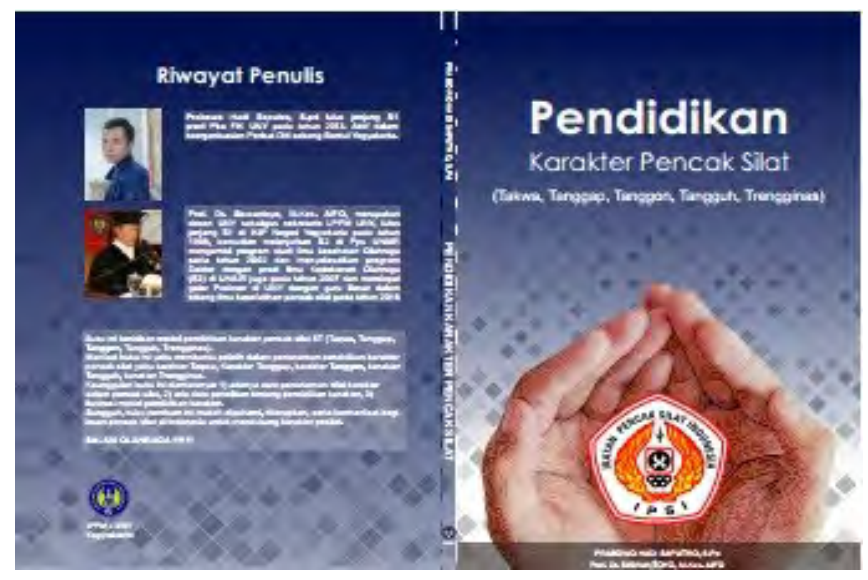

Fig. 2. Final Product Book Cover

The book of pencak silat character education contains the research background in chapter 1. Chapter 2 contains literature review of character education, character education model, pencak silat, history of pencak silat, aspects and values, and character values in pencak silat. Chapter 3 discusses the cultivation of taqwa, tanggung jawab, tanggon, tangguh and trengginas. Chapter 4 contains the results of the research on pencak silat character education in Yogyakarta. In Chapter 5, the implementation of the Pencak Silat character education model is explained.

\section{CONCLUSION}

Overall, the pencak silat character education model is effectively used for trainers or pencak silat athletes after being implemented in two stages of testing and the effectiveness test of $\mathrm{T}$ test at 19.556> t table 2.032, and a significance value of $0.000<0.05$. This development research can be used for cultivating pencak silat character education.

\section{REFERENCES}

[1] A. Buchori, R. Dwi Setyawati, "Development Learning Model Of Charactereducation Throughe-Comic In Elementary School," 2015, 3(9). International Journal of Education and Research. Retrieved fromhttps://www.ijern.com/journal/2015/September-2015/30.

[2] A. Hidayati, M. Zaim, K. Rukun, Darmansyah. "The Development Of Character Education Curriculum For Elementary Student In West Sumatera," Journal of Education and Research. 2014. Retrieved from https://www.ijern.com/journal/June-2014/16.pdf .i8/2.pdf.

[3] Hayah, Character education in islamic boarding school and the implication to students' attitude and critical thinking skills on biodiversity learning. Journal of Physics. 2017. http://doi:10.1088/1742-6596/812/1/012101

[4] Dermawan Hendra. "A Model Of Character Education As Reflected In Fauady's The Land Of Five Towers," Journal on Studies in English 
Language and Literature (IJSELL). 2015. Retrieved from https:// www.arcjournals.orgorg/pdfs/ijsell/v3-

[5] A. Tannr, A. Al-Hroub, "Effects Of Character Education On The SelfEsteem Of Intellectually Able And Less Able Elementary Students In Kuwait," Journal of Special Education, 2013, 28(2). Retrieved from https://eric.ed.gov/?id=EJ1023237.

[6] A. Pala, "The Need For Character Education," Journal Of Social Sciences And Humanity Studies, 2011. 3,(2). Retrieved from http://www.sobiad.org/arhieves/2011_2

[7] B. W. Marvin. What Works in values education. Journal Of Educational Research. 2011. http://dx.doi.org/10.1016/j.ijer.2011.07.003

[8] C. Klein-Ezell, D. Ezell, "Character education using children's literature, puppets, magic tricks and balloon," Journal of Humanities and SocialScience. 2014. Retrieved from http://www.ijhssnet.com.

[9] E. T. Widyahening, N. E. Wardhani, "Literary Works and Character Education," jurnal American Research Institute for Policy Development. 2016. https://doi.org/10.15640/ijll.v4n1a20.

[10] A. Agboola, K. C. Tsai, "Bring Character Education into Classroom. Journal of Environmental \& Science," 2012. Retrieved fromhttps://files.eric.ed.gov/fulltext/EJ10863

[11] Notosoejitno. Khazanah Pencak Silat. Jakarta : CV. Infomedia, 1997.

[12] Jalaludin. Membangun SDM Bangsa Melalui Pendidikan Karakter. Jurnal Lembaga Penelitian dan Pengabdian Kepada Masyarakat. 2012. Retrieved From htttp://jurnal.upi.edu

[13] H. Karatay, Transfer of values in the Turkish and Western children's literary works: Character education in Turkey. 2011. Jurnal Educational Research and Reviews. Retrieved from https://www.academicjournals.org/article/article1379691398

[14] L. Nucci, D. Narvaez, Handbook of Moral and Character Education. Routledge. New York, N.Y : Taylor \& Francis Grup. 2008.
[15] K. Kristjan, Ten Myths About Character, Virtue and Virtue Education -Plus Three Well-Founded Misgivings. British Journal of Educational Studies. 2013. https://Doi:10.1080/00071005.2013.778386

[16] Mulyasa, E. Manajemen Pendidikan Karakter. Jakarta: Bumi Aksara. 2014.

[17] Kusumandari, et al. "Character Education Development ModelBased E-Learning and Multiple Intelegency In Childhood In Central Java," 2015. Global Journal of Computer Science and Technology. Retrieved from https:// www.globaljournals.org

[18] I. Nzekwu, Language Education for Character and Skill Development in Nigeria. Journal of Arts and Humanities. 2016. (IJAH).http://dx.doi.org/10.4314/ijah.v5i3.4

[19] F. Turan, I. Ulutas, Using Storybooks as a Character Education Tools. Journal of Education and Practice. 2016. Retrieved fromhttps://files.eric.ed.gov/fulltext/EJ1103139

[20] N. A. Wiyani, Manajemen pendidikan karakter: konsep dan implementasinya di sekolah. Yogyakarta: Pedagogia. 2012.

[21] G. M. Almerico, "Building character through literacy with children's literature," Research in Higher Education Journal. 2014. Retrieved fromhttps://www.aabri.com/manuscripts/141989

[22] CEP. A Framework for School Success: Eleven Principles of Effective Character Education. 2014.

[23] E. Kriswanto, "Pencak Silat Sejarah dan Perkembangan Pencak Silat, Teknik-Teknik dalam Pencak Silat, Pengetahuan Dasar Pertandingan Pencak Silat,” Yogyakarta: Pustaka Baru Press. 2015.

[24] O’ong Maryono. Pencak Silat Merentang Waktu. Yogyakarta: Galang Press. 2000.

[25] M. Kartomi, Traditional and Modern Forms of Pencak Silat in Indonesia: The Suku Mamak in Riau. Jurnal Musicology Australia. 2011. https://doi:10.1080/08145857.2011.580716

[26] Sugiyono. Metode penelitian kuantitatif, kualitatif, dan R\&D. Bandung: Alfabeta. 2016. 